\title{
The impact of Australia's distinctive nature and ecology on imperial expansion in the first years of settlement in New South Wales
}

\section{Lucinda Janson}

Australia's nature and ecology have been shaped over millennia by geological and climatic factors into a distinctive and complex ecosystem. The continent's Aboriginal peoples adapted to the challenges of a variable and often hostile climate and landscape, and developed a sophisticated means of living off the land. Yet the arrival of a fleet of British ships to what would become known as New South Wales permanently altered this balance. The land would eventually be shaped by these invaders into what Alfred Crosby called a 'neo-Europe'. ${ }^{1}$ Australia's European colonisers had a complex and ever-changing relationship with the Australian landscape. During the early years of settlement in New South Wales, Europeans struggled to establish and maintain an imperial colony in a strange land. Their reluctance to understand the Aborigines and their connection with the indigenous plants and animals initially had harmful consequences for the imperial project.

1 Alfred Crosby, Ecological Imperialism: The Biological Expansion of Europe, 900-1900 (Cambridge: Cambridge University Press, 1986), 2. 
Overcoming this early resistance, the settlers soon began to adapt their farming practices and even their diet to the new environment. Yet the 'foreign' aspects of Australia's nature and ecology caused many Europeans to react by imposing their own plants and animals in order to 'improve' the land. Moreover, while some colonists praised and admired the landscape, others used the image of the city replacing the bush to demonstrate that the Europeans' imperial achievement had involved a rejection of Australia's distinctive nature. This unsteady and unsettled process of colonisation left an enduring imprint on the European occupation of Australia, and revealed significant dynamics in the broader processes of settler colonialism itself.

Australia's distinctive ecological characteristics developed as a result of a number of complex processes. Australia's lack of geological activity and large-scale glaciation meant that its soil has very few nutrients. ${ }^{2}$ Moreover, its unpredictable climate is a result of the El Niño Southern Oscillation (ENSO), which can bring droughts, bushfires and fierce winds. ${ }^{3}$ Australia's infertile soil, changeable climate and unpredictable rainfall mean that plants and animals have evolved in a system of co-operative ecology in order to make the most of the country's scarce resources. ${ }^{4}$ Moreover, fire has developed as an integral part of the landscape. Since the poor soil could not support large herbivores, fire - often in the form of huge bushfires - took on the role of recycling plant matter. When the Aborigines arrived, they developed a method of lighting controlled, low-intensity fires partly to prevent such disastrous bushfires. The Aborigines equally used fire to facilitate travel, hunt, signal, regenerate and cultivate plants, and clear access to edible roots. ${ }^{5}$ Such deliberate manipulation of the land was crucial to the Aborigines' survival in this harsh and unpredictable landscape. Indeed, Bill Gammage describes the pre-contact Aborigines as

2 Tim Flannery, The Future Eaters: An Ecological History Lands and Peoples, 2nd ed. (Sydney: Reed New Holland, 2005), 76-78.

3 Ibid., 81-83.

4 Flannery, Future Eaters, 84.

5 Stephen J. Pyne, Burning Bush: A Fire History of Australia, (New York: Henry Holt, 1991), 95-98; Flannery, Future Eaters, 223. 
'farmers' who 'tended' both plants and animals and controlled their own food supply. ${ }^{6}$ Eric Rolls claims that before the arrival of the Europeans, 'everything in Australia was in a state of balance'.

Yet with the arrival of the First Fleet in 1788, the Europeans were confronted with a strange land which they often did not understand or appreciate. Tom Griffiths claims that the Europeans viewed the Australian land and people as 'ancient, primitive and endemically resistant to progress', while even its animals were seen as 'undeveloped' ${ }^{8}$ Such judgements reflected the Europeans' confused and defensive reaction to an ecology and a way of living in a land very different from their own. This reaction allowed the Europeans to legitimise their colonisation by casting themselves as superior to the 'savage' Aborigines.

Their failure to appreciate the Aborigines' knowledge is evident in the Europeans' responses to fire. Although many early observers recognised that the Aborigines set fire to the land, they were at a loss to understand why, and certainly did not see it as a crucial land management practice. Thus, Watkin Tench noted that the Aborigines were 'perpetually setting fire to the grass and bushes', yet he disapproved of the practice, believing it 'contributes to render small quadrupeds scarce'. ${ }^{9}$ Moreover, the surgeon George Bouchier Worgan noted that he had observed 'a great Fire' which he assumed the Aborigines had lit but he could not 'conjecture' for what

6 Bill Gammage, The Biggest Estate on Earth: How Aborigines Made Australia, (Sydney: Allen \& Unwin, 2011), 281-82.

7 Eric Rolls, From Forest to Sea: Australia's Changing Environment, (Brisbane: University of Queensland Press, 1993), 167.

8 Tom Griffiths, 'Ecology and Empire: Towards and Australian History of the World,' in Ecology and Empire: Environmental History of Settler Societies, ed. Tom Griffiths and Libby Robin, (Edinburgh: Keele University Press, 1997), 3.

9 Watkin Tench, A Complete Account of the Settlement at Port Jackson, (London: G. Nicol and J. Sewell, London, 1793; Sydney: University of Sydney edition, 1998), 118, www.sl.nsw. gov.au/discover_collections/history_nation/terra_australis/published_accounts/tench/ index.html. 
purpose. He could also deny the Aborigines agency in lighting the fires, remarking that 'I have been induced to impute them to accident, from the Natives carrying lighted touch-wood about the Country with them' ${ }^{10}$

Such an unthinking dismissal of an ancient practice is characteristic of the Europeans' views of the Aborigines as uncivilised and backward. John Hunter provides another example of a European observer who failed to understand the Aborigines' sophisticated and thriving lifestyle, when he remarked that 'the Land seems to afford them but a very scanty Sustenance', and claimed that they only lived along the coast. ${ }^{11}$ This failure to understand the Aborigines' ways of managing the land was a way for the Europeans to justify their imperial expansion. In refusing to believe that the Aborigines managed their land, the settlers could see themselves as its rightful workers. Indeed, Tench describes himself and his companions as 'new lords of the soil', implying natural superiority over the Aborigines.

Grace Karskens claims that "the belief that a people could only "own" land if they exploited it was part of a long tradition of natural law ideas of property'. ${ }^{12}$ Nicole Graham claims that the Europeans' notion of the 'improvement' of the land rested on the idea that food production, as opposed to hunting and gathering, was the ideal form of society. She suggests that the difficulties the Europeans faced in achieving the imperialistic ideal of settled agriculture encouraged them to persist rather than to adapt their farming methods. ${ }^{13}$

Despite their arrogance, the Europeans faced great challenges in working the land and especially in creating a self-sufficient colony. Their lack of knowledge about the different and unpredictable landscape led to many hardships in the first years of settlement. In his letters to Lord Sydney,

10 George Bouchier Worgan, 'Journal Kept on a Voyage to New South Wales with the First Fleet, with Letter Written to his Brother Richard, 12-18 June 1788', First Fleet Collection of journals, correspondence and drawings, ca 1786-1802, Mitchell Library, State Library of New South Wales, and transcript online at acms.sl.nsw.gov.au/_transcript/2015/D33332/ al175.html\#al175009, 34.

11 John Hunter, 'Journal kept on board the Sirius during a voyage to New South Wales, May 1787-March 1791', First Fleet Collection of journals, correspondence and drawings, ca 1786-1802, Mitchell Library, State Library of New South Wales, and transcript online at acms.sl.nsw.gov.au/_transcript/2007/D00007/a1518.html\#a1518009, 90.

12 Grace Karskens, The Colony: A History of Early Sydney, (Sydney: Allen \& Unwin, 2009), 36.

13 Nicole Graham, Lawscape: Property, Environment, Law, (Oxford: Routledge, 2011), 126. 
Governor Arthur Phillip was forced to repeatedly urge that 'a regular supply of provisions from England will be absolutely necessary for four or five years' since the colony could not produce sufficient food supplies. ${ }^{14}$ Many observers noted the initial failure of the colony's crops. Arthur Bowe Smyth, surgeon on board the Lady Penrhyn, pessimistically reported that the soil, 'when exposed to the intense heat of the Sun by removing the surrounding trees, is not fit for the vegitation [sic] of anything even the grass itself'. ${ }^{15}$ In November 1790, Tench recorded that 'cultivation, on a public scale, has for some time past been given up here' since 'wheat returned so poorly last harvest', while vegetables were equally 'in wretched condition' ${ }^{16}$ In the same year, Tench inspected the crops of the Reverend Johnson, who he described as 'the best farmer in the country'. Despite this praise, Tench was largely unimpressed by his crops, claiming that the 'best wheat' was 'tolerable' and that other patches were 'very bad'. ${ }^{17}$

Among the challenges of adaptation, Europeans began to experience Australia's variable climate, which swung suddenly from one extreme to another. They faced not only droughts, but also floods and bushfires. Collins reported that in December 1792 'the country ... was everywhere on fire'.$^{18}$ This bushfire was one of many caused by the Europeans' lack of understanding of the Aboriginal fire regime, and the importance of controlled burning to prevent large-scale fires. ${ }^{19}$ The Europeans' first experience of a 'true' flood occurred in May 1799, when the Hawkesbury River rose 15 metres and crops and houses were swept away. Such a destructive event came as a great shock to the farmers, despite warnings by

14 Phillip to Sydney, 9 July 1788, in Historical Records of Australia (HRA), Series 1, Vol. 1, ed. Frederick Watson, (Sydney: Library Committee of the Commonwealth Parliament, 1914), 46.

15 Arthur Bowes Smyth, 'A Journal of a Voyage from Portsmouth to New South Wales and China in the Lady Penrhyn, 1787-1789', First Fleet Collection of journals, correspondence and drawings, ca 1786-1802, Mitchell Library, State Library of New South Wales, and transcript online at acms.sl.nsw.gov.au/_transcript/2007/D00007/a1085.html\#a1085009, 41.

16 Tench, Complete Account, 53-54

17 Ibid., 55

18 David Collins, An Account of the English Colony in New South Wales, Vol. 1, ed. Brian H. Fletcher, (London: T. Cadell Jun. and W. Davies, 1798; Sydney: A. H. \& A. W. Reed, 1975), 216. 19 Karskens, Colony, 272-73. 
the local Aboriginal people. ${ }^{20}$ These examples demonstrate the difficulties the Europeans experienced when faced with a climate and nature very different from their own.

This lack of knowledge about Australia's distinctive ecosystem almost threatened the survival of the colony, which at first relied almost exclusively on supplies brought in from Britain. By October 1789 there were fears about how long provisions would last, and rations were reduced. Collins records that around this time the last of the butter brought from England was finished - the first provision to completely run out. ${ }^{21}$ In April 1790, the colony was still waiting for an English ship to arrive. Tench anxiously noted that at this time the settlement's salt pork would last until July, the flour until August and rice until October. ${ }^{22}$ English ships carrying more provisions - and convicts - finally arrived in June. ${ }^{23}$ Such hardships were a result of the European refusal to come to terms with the foreign environment in which they found themselves.

During these months of famine, the settlers were forced to adapt and rely more on native sources of food. Thus, Collins notes that 2,000 pounds of fish were caught in one month, and used to supplement the English rations, while Tench writes of hunting for kangaroos during this period. ${ }^{24}$ Although native plants were denigrated, many observers noted and even seemed to enjoy the edible varieties. Midshipman (later second Lieutenant) Newton Fowell described many such plants, including a cabbage he claimed was 'very good eating', 'some small green berries' which had 'a very pleasant strong tartness' and 'a plant very like the Spinage in England which afford us a most excellent repast'. He equally noted that a number of these plants were 'very good for the Scurvey'. ${ }^{25}$ Such examples of European acknowledgement of the uses and benefits of indigenous plants suggest that even during this early period they began, to a certain extent, to adapt to their new environment.

20 Ibid., 131.

21 Collins, An Account, 66.

22 Tench, Complete Account, 33.

23 Collins, An Account, 93.

24 Ibid., 92; Tench, Complete Account, 33.

25 Newton Fowell, 'Letter to his Family, 12 July 1788', First Fleet Collection of journals, correspondence and drawings, ca 1786-1802, Mitchell Library, State Library of New South Wales, and transcript online at www.sl.nsw.gov.au/discover_collections/history_nation/ terra_australis/letters/fowell/index.html, 20-23. 
Karskens claims that the Europeans farmers also adopted numerous 'pragmatic measures' which were 'adapted' to the peculiar Australian situation. ${ }^{26}$ She suggests that early accounts denigrated farmers in New South Wales since their practices did not conform to the idea of the 'English rural idyll', and they did not make use of new notions of scientific breeding, crop rotation and intensive cultivation. Instead, the settlers adapted to the Australian conditions and 'quickly worked out a sort of rough environmental and economic logic by trial and error' ${ }^{27}$ This meant, for example, using the hoe rather than the plough and planting crops of hardier maize rather than of wheat. There was also much experimentation with different types of grain, and different methods of planting them. Tench recorded in 1790 that farmers were beginning to understand the land. The Reverend Johnson had found that the beginning of May was the best time to sow barley. ${ }^{28}$ Indeed, the colony gradually became more productive and able to support the growing European population. Collins noted that in 1794 the colony had enough stores of maize and wheat to last for 43 weeks, which he claimed was 'an abundance' that could successfully prevent the 'evil hour of want and distress'. ${ }^{29}$

Despite these successes, Jared Diamond claims that the settlers never truly succeeded in creating 'a literate, food-producing, industrial democracy in Australia'. Instead, they simply imported all the elements of their colony from outside Australia, drawing on technologies developed in a different environment. ${ }^{30}$ Thus, although the Europeans gained some knowledge of the land in which they had settled, to a large extent they responded to the Australian ecology by ignoring and attempting to supersede it.

Indeed, to a large extent, it was not the Europeans' adaptation to Australia's distinctive environment, but their conscious decision to reshape it which truly drove their imperial expansion. Their reluctance to understand the land and how it had already supported human life made it easier for them to simply impose their own worldview. Thus the foreignness of the colony's ecology meant that the land became a blank canvas on which an imperial vision could be established. Geoffrey Bolton writes that the

\footnotetext{
26 Karskens, Colony, 116.

27 Ibid., 115.

28 Tench, Complete Account, 55.

29 Collins, An Account, 289.

30 Jared Diamond, Guns, Germs and Steel, rev. ed. (London: Vintage, 2005), 321.
} 
British colonisers brought with them the notion that 'men had a right and duty to transform the environment into greater productivity'. ${ }^{31}$ Thus, observers often reacted to Australia's unique flora and fauna by considering how it could be 'improved' and rendered more European. Tench talks of 'cutting down and burning' trees as the only 'impediment' to cultivation of the land..$^{32}$ Phillip wrote that 'this country at present does not furnish the smallest resource except in fish', suggesting that it was up to the Europeans to render the land productive and fruitful. ${ }^{33}$ It is also significant that the Europeans named the native plants they observed after European ones, thus refusing to accept Australia's distinctive ecology. In a letter to Lord Sydney, Phillip describes the 'wild celery, spinages, samphose, a small wild fig, and several berries, which have proved very wholesome', the English names symbolically suggesting ownership. ${ }^{34}$ Tench writes that during an early exploratory expedition to Richmond Hill, 'potatoes, maize, and garden seeds of various kinds were put into the earth', implying that the planting of European species could indicate possession of the land. ${ }^{35}$ Yet the landscape was not only altered deliberately by planting and cultivation, but also by exotic plants and animals run wild. The 'cotton-plant', for example, escaped from farms and was soon found in paddocks and along roads throughout the colony. ${ }^{36} \mathrm{~A}$ diverse range of plants, including geraniums, peach trees, blackberries, the privet and the willow similarly aided the Europeans' imperial expansion by taking over much of the landscape. ${ }^{37}$

Although the Europeans certainly altered the landscape considerably, and thus tampered with Australia's distinctive nature, many early observers appreciated Australia for its exotic and unique nature. Such admiration also established European domination of New South Wales, since by recognising the beauty of the country, and seeking to catalogue it, they were effectively establishing a claim to the land. Karskens writes of the 'rage for curiosity' which overtook many of the colonists, as they collected

31 Geoffrey Bolton, Spoils and Spoilers: Australians Make their Environment, 1788-1980, (Sydney: Allen \& Unwin, 1981), 11.

32 Tench, Complete Account, 25.

33 Phillip to Nepean, 9 July 1788, HRA, 55.

34 Philip to Sydney, 15 May 1788, HRA, 23.

35 Tench, Complete Account, 24.

36 Karskens, Colony, 267.

37 Ibid., 268-69. 
plant specimens, described the flora and fauna and even painted it. Many were writing and producing art for an audience 'back home'. Bernard Smith claims that Australia's 'natural curiosities aroused the interest of the British public far more than the story of the foundation of the penal settlement' ${ }^{\prime 38}$ Indeed, the accounts and letters of the early colonists are filled with remarks on exotic and exciting flora and fauna. Worgan seemed especially attracted by the picturesque nature of his surroundings. He described the country as 'consisting of gentle risings \& Depressions, beautifully clothed with variety of Verdures of Evergreens' and seemed enchanted by the land which included 'Here, a romantic rocky, craggy Precipice over which, a little purling stream makes a Cascade. There, a soft vivid-green, shady Lawn' ${ }^{39}$ Many recorded their impressions in paintings and drawings, both of landscape scenes and of detailed images of native flora and fauna. Yet not all paintings depicted such an idealised view of Australia's nature. Instead, the topographical paintings of the period told a narrative of the stages of social evolution - from the 'savage' hunters and gatherers to the 'civilised' farmers and commercial men. One such artist, James Wallis, contrasted the Aborigines in the 'desolate wilderness' with a view of Sydney and its harbour. Robert Dixon claims that this image of the triumph of the city over the Australian nature represented for Wallis 'the consummation of empire in a commercial city'.$^{40}$ Thus, the European settlers did not seek to come to terms with, but rather tried to replace, Australia's native ecology in order to fulfil their imperial ambitions.

Australia's distinctive nature and ecology shaped the experience of European settlers in New South Wales in a number of ways. The colonisers sought to denigrate and ignore the environment, but it played a role both in the near failure of their society and their survival in Australia's hostile climate. To a certain extent, the Europeans were able to adapt to the landscape and even appreciate it, yet much of the success of their imperial project lay in their conscious rejection of the distinctiveness of Australia's nature.

38 Bernard Smith, European Vision and the South Pacific, 2nd ed., (Sydney: Harper and Row, 1984), 163

39 Worgan, 'Journal', 8.

40 Robert Dixon, Course of Empire: Neo-Classical Culture in New South Wales, 1788-1860, (Oxford: Oxford University Press, 1986), 61-62. 


\section{References}

Bolton, Geoffrey. Spoils and Spoilers: Australians Make their Environment, 1788-1980. (Sydney: Allen \& Unwin, 1981).

Collins, David. An Account of the English Colony in New South Wales, Vol. 1, edited by Brian H. Fletcher. (London: T. Cadell Jun. and W. Davies, 1798; Sydney: A. H. \& A. W. Reed, 1975).

Crosby, Alfred. Ecological Imperialism: The Biological Expansion of Europe, 900-1900. (Cambridge: Cambridge University Press, 1986).

Diamond, Jared. Guns, Germs and Steel, rev. ed. (London: Vintage, 2005).

Dixon, Robert. Course of Empire: Neo-Classical Culture in New South Wales, 1788-1860. (Oxford: Oxford University Press, 1986).

Flannery, Tim. The Future Eaters: An Ecological History Lands and Peoples, 2nd ed. (Sydney: Reed New Holland, 2005).

Fowell, Newton. 'Letter to his Family, 12 July 1788', First Fleet Collection of journals, correspondence and drawings, ca 1786-1802, Mitchell Library, State Library of New South Wales, and transcript online at www.sl.nsw. gov.au/discover_collections/history_nation/terra_australis/letters/ fowell/index.html.

Gammage, Bill. The Biggest Estate on Earth: How Aborigines Made Australia. (Sydney: Allen \& Unwin, 2011).

Graham, Nicole. Lawscape: Property, Environment, Law. (Oxford: Routledge, 2011).

Griffiths, Tom. 'Ecology and Empire: Towards and Australian History of the World', in Ecology and Empire: Environmental History of Settler Societies, edited by Tom Griffiths and Libby Robin. (Edinburgh: Keele University Press, 1997), 1-16.

Hunter, John. 'Journal kept on board the Sirius during a voyage to New South Wales, May 1787-March 1791', First Fleet Collection of journals, correspondence and drawings, ca 1786-1802, Mitchell Library, State Library of New South Wales, and transcript online at, acms.sl.nsw.gov. au/_transcript/2007/D00007/a1518.html\#a1518009. 
Karskens, Grace. The Colony: A History of Early Sydney. (Sydney: Allen \& Unwin, 2009).

Phillip to Nepean, 9 July 1788, in Historical Records of Australia (HRA), Series 1, Vol. 1, edited by Frederick Watson, Sydney: Library Committee of the Commonwealth Parliament, 1914.

Phillip to Sydney, 15 May 1788, in Historical Records of Australia (HRA), Series 1, Vol. 1, edited by Frederick Watson, Sydney: Library Committee of the Commonwealth Parliament, 1914.

Phillip to Sydney, 9 July 1788, in Historical Records of Australia (HRA), Series 1, Vol. 1, edited by Frederick Watson, Sydney: Library Committee of the Commonwealth Parliament, 1914.

Pyne, Stephen J. Burning Bush: A Fire History of Australia. (New York: Henry Holt, 1991).

Rolls, Eric. From Forest to Sea: Australia's Changing Environment. (Brisbane: University of Queensland Press, 1993).

Smith, Bernard. European Vision and the South Pacific, 2nd ed. (Sydney: Harper and Row, 1984).

Smyth, Arthur Bowes. A Journal of a Voyage from Portsmouth to New South Wales and China in the Lady Penrhyn, 1787-1789', First Fleet Collection of journals, correspondence and drawings, ca 1786-1802, Mitchell Library, State Library of New South Wales, and transcript online at acms.sl.nsw.gov.au/_transcript/2007/D00007/a1085. html\#a1085009.

Tench, Watkin. A Complete Account of the Settlement at Port Jackson. (London: G. Nicol and J. Sewell, London, 1793; Sydney: University of Sydney edition, 1998). www.sl.nsw.gov.au/discover_collections/ history_nation/terra_australis/published_accounts/tench/index.html.

Worgan, George Bouchier. 'Journal Kept on a Voyage to New South Wales with the First Fleet, with Letter Written to his Brother Richard, 1218 June 1788', First Fleet Collection of journals, correspondence and drawings, ca 1786-1802, Mitchell Library, State Library of New South Wales, and transcript online at acms.sl.nsw.gov.au/_transcript/2015/ D33332/al175.html\#a1175009. 
This text is taken from Merici, Volume 1, 2015, edited by Henry Poetrodjojo, Ilze Alexander and Lauren Prossor, published 2016 by ANU eView, The Australian National University, Canberra, Australia. 